\title{
Role of Tinospora cordifolia in metabolic health disorders: An updated review
}

\author{
Available online at www.hjhs.co.in
}

REVIEW ARTICLE

Pritika Devi*

Assistant Professor, Dept. of Rasa Shastra \& Bhaishjya Kalpana, Babe Ke Ayurvedic Medical

College \& Hospital, Daudhar, Moga, Punjab, India.

DOI $\underline{10.22270 / h j h s . v 6 i 1.91}$

\begin{abstract}
The use of various herbal drugs in India has been widely developed in recent years. Guduchi (Tinospora cordifolia) belonging to family Menispermaceae has a tremendous amount of bioactive principles in exploring nutraceuticals from natural source. T. cordifolia is considered as an important herbal drug of traditional system of Indian Medicines. The herb is also well known for its therapeutic efficacy in treatment of various diseases viz. dyspepsia, diabetes, fever, urinary problems, jaundice, chronic diarrhoea, cardiac disease, dysentry, helmenthiasis, skin diseases, leprosy, thyroidand various metabolic diseases. Present review highlights the antidiabetic, hypolipidemic activity of Guduchi and their validation through existing literature, experimental studies. The plant is reported to have various alkaloids, glycosides, steroids and terpenoids. The current study is undertaken to explore and review its role on metabolic disorders.
\end{abstract}

Keywords: Tinospora cordifolia, Guduchi, metabolic disorder, antidiabetic, hypolididemic

\section{Introduction}

The global population is facing a surge in metabolic and lifestyle disorders, and the contemporary system of medicine is having limited efficacy to manage these disorders in effective and safe manner. (1-3) Metabolism is the breaking down of food to its simpler components: proteins, carbohydrates (or sugars), and fats. Metabolic disorders occur when these normal processes become disrupted. Disorders in metabolism can be inherited, in which case they are also known as inborn errors of metabolism, or they may be acquired during your lifetime. (4) Type 2 Diabetes Mellitus (T2DM) is a cluster of abnormal metabolic paradigms with the essential feature of hyperglycaemia and is dubbed as the disease of "premature ageing". Incidence of $\mathrm{T} 2 \mathrm{DM}$ is rising all over the world at worrying rate, despite, comprehensive and coordinated effects of World Health Organization (WHO), International Diabetes Federation and Several Social Science Agencies. (5) $6.6 \%$ of the world population was affected by this disease in 2010 with an estimated 285 million carriers and the number may become almost double
(552 million) by 2030. India is facing an even grimmer scenario. On the basis of affected population, both in terms of percentage and numbers India has significantly more patients than China and other neighbouring countries and is often referred to as the diabetic capital of the world. (6)

Metabolic syndrome is a cluster of conditions that occur together, increasing your risk of heart disease, stroke and type 2 diabetes. These conditions include increased blood pressure, high blood sugar, excess body fat around the waist, and abnormal cholesterol or triglyceride levels. Metabolic syndrome is closely linked to overweight or obesity and inactivity. It's also linked to a condition called insulin resistance. Normally, your digestive system breaks down the foods you eat into sugar. Insulin is a hormone made by your pancreas that helps sugar enter your cells to be used as fuel. In people with insulin resistance, cells don't respond normally to insulin and glucose can't enter the cells as easily. As a result, your blood sugar levels rise even as your body churns out more and more insulin to try to lower your blood sugar. (7) 
Ayurveda holistic dietary and lifestyle management approaches and regimens of natural product based medicines offers timetested and effective solutions for diabetes and related metabolic disorders. (8-10) Ayurveda explains metabolic disorders as agnivaishamya (problems in digestion, absorption). This condition occur due to vitiation of digestive fire, this can happen due to doshic imbalance a condition occur due to blockage in the individual channels of metabolism, as a result of this excess or improper digestion and absorption occur, and results in disease. (11) Tinospora cordifolia (Guduchi) is one of the components of several traditional formulations with potent rejuvenating, immunomodulatory, cytoprotective, and antioxidant properties that help to manage disordered physiological processes of body. (12-14) Tinospora cordifolia (Guduchi) composed of so many different chemicals constituents that might have effect on various system of human body. Different experimental or clinical studies have shown its effect as antioxidant, immunomodulatory, anticancerous, antidiabetic, anti hyperlipidemic. So many scientific evidences are also available for its anti-diabetic potency, anti hyperlipidemic properties associated with cardioprotective agent on various animal and human models. Various classical Ayurvedic texts and Nighantu (Ayurvedic materiamedica) have described its anti-diabetic usages under various names viz. Pramehaghna, Pramehahara, Mehaghna and Mehahara. (15-19) Ayurvedic Pharmacopoeia of India has also cited its antidiabetic utility. (20) Tribals of Korkus (Melghat, Maharashtra, India) have been using the herb for polyuria, diabetes and fever. (21) Various dosage forms of Guduchi and wide array of its active, natural principles and crude extracts have been used in traditional system of medicine and have reported anti-diabetic, antihyperlipidemic activity experimentally or clinically in numerous scientific journals. These constituents directly or indirectly affect various metabolic cascades and influence the level of glucose. (22) The present review highlights the efficacy of Tinospora on various metabolic disorders.

\section{Collection of Data}

Published information on Tinospora cordifolia were collected from several review articles, experimental studies and some crossreferences were collected. Recent developments research on role of Tinospora cordifolia on various metabolic disorders (Table 1), covering all available records and articles inPubmed, Scopemed, Dharaand other associated databases including fields of pharmacological research articles were also reviewed. Present review article is restricted to the role of plant in metabolic disorders.

\section{Discussion}

Tinospora cordifolia (Family: Menispermaceae), a well-known medicinal plant of Ayurveda isused in therapeutics as a single herb as well as is an essential ingredient of several polyherbal Ayurvedic formulations. $(23,24)$ Time-to-time several classical dosage forms of Tinospora cordifolia are being developed by adopting classical pharmaceutical doctrines of Ayurveda. (25-28) These dosage forms are being used in traditional practice as a rejuvenative, health promotive, as well as curative medicine in wide range of disorders. (29-31)

Table 1. Pharmacological effects of Tinospora cordifolia in different metabolic disorders

\begin{tabular}{l|l|l|l|l|l|}
\hline Part & \multicolumn{1}{|c|}{ Extract } & $\begin{array}{c}\text { Experimental/ } \\
\text { Clinical }\end{array}$ & \multicolumn{1}{|c|}{ Dose } & $\begin{array}{c}\text { Duration } \\
\text { for } \\
\text { Treatment }\end{array}$ & \multicolumn{1}{|c|}{ Effect } \\
\hline Root & Aqueous & Alloxan-rats & $400 \mathrm{mg} / \mathrm{kg}$ & $\begin{array}{l}3 \text { to } 15 \\
\text { weeks }\end{array}$ & Antihyperglycemic. (32) \\
\hline Root & Aqueous & albino rats & $\begin{array}{l}2.5 \mathrm{gm} / \mathrm{kg}, \\
5 \mathrm{gm} / \mathrm{kg},\end{array}$ & 6 weeks & $\begin{array}{l}\text { Lowers the serum } \\
\text { glucose level. (33) }\end{array}$ \\
\hline
\end{tabular}




\begin{tabular}{|c|c|c|c|c|c|}
\hline & & & $7.5 \mathrm{gm} / \mathrm{kg}$ & & \\
\hline Root & Alcoholic & Alloxan rats & $400 \mathrm{mg} / \mathrm{kg}$ & 4months & $\begin{array}{l}\text { Lowers the plasma } \\
\text { glucose level. (34) }\end{array}$ \\
\hline Stem & Alcoholic & Alloxan rats & $500 \mathrm{mg} / \mathrm{kg}$ & 6weeks & $\begin{array}{l}\text { Decreased glucose- 6- } \\
\text { phosphatase, fructose } 1 \text {, } \\
6 \text { - bi- phosphatase. (35) }\end{array}$ \\
\hline Stem & Alcoholic & Alloxan rats & $20 \mathrm{ml} / \mathrm{kg}$ & $\begin{array}{l}2 \text { to } 30 \\
\text { days, twice } \\
\text { day }\end{array}$ & $\begin{array}{l}\text { Hypoglycemic effect. } \\
(36)\end{array}$ \\
\hline Stem & $\begin{array}{l}\text { Aqueous, } \\
\text { Ethanol, } \\
\text { Methanol }\end{array}$ & $\begin{array}{l}\text { Albino mice } \\
\text { (Ehrlich ascites } \\
\text { tumor (EAT) } \\
\text { cells) }\end{array}$ & $1-100 \mathrm{mg}$ & - & $\begin{array}{l}\text { Glucose uptake } \\
\text { stimulatory activity of } \\
\text { the lyophilized extracts } \\
\text { of T. cordifolia viz; } \\
\text { aqueous, ethanol and } \\
\text { methanol were evaluated } \\
\text { for glucose uptake at } \\
\text { different dosages. (37) }\end{array}$ \\
\hline Root & Alcoholic & Alloxan rats & $100 \mathrm{mg} / \mathrm{kg}$ & 6 weeks & $\begin{array}{l}\text { Hypoglycemic effect. } \\
(38)\end{array}$ \\
\hline Root & Methanolic & $\begin{array}{l}\text { Alloxan, } \\
\text { streptomycin } \\
\text { induced rat }\end{array}$ & $150 \mathrm{mg} / \mathrm{kg}$ & - & $\begin{array}{l}\text { Hypoglycemic effect. } \\
(39)\end{array}$ \\
\hline $\begin{array}{l}\text { Stem } \\
\text { bark }\end{array}$ & Alcoholic & Albino rat & $250 \mathrm{mg} / \mathrm{kg}$ & 90days & $\begin{array}{l}\text { Hypoglycemic effect. } \\
(40)\end{array}$ \\
\hline Stem & Alcoholic & Human & $\begin{array}{l}125 \mathrm{mg} / \mathrm{kg} \\
250 \mathrm{mg} / \mathrm{kg}\end{array}$ & $\begin{array}{l}1 \text { to } 2 \\
\text { weeks }\end{array}$ & $\begin{array}{l}\text { Non -significant result } \\
\text { on serum glucose level. } \\
(41)\end{array}$ \\
\hline Stem & $\begin{array}{l}\text { Isoquinoline } \\
\text { alkaloid rich } \\
\text { fraction }\end{array}$ & $\begin{array}{lr}\text { Normal } & \text { and } \\
\text { glucose-loaded } \\
\text { Wistar rats } \\
50.0, & 100.0, \\
200.0 & \end{array}$ & $\begin{array}{l}50 \mathrm{mg} / \mathrm{kg} \\
100 \mathrm{mg} / \mathrm{kg} \\
200 \mathrm{mg} / \mathrm{kg}\end{array}$ & - & $\begin{array}{l}\text { Hypoglycemiceffect via } \\
\text { mechanisms of insulin } \\
\text { releasing and insulin- } \\
\text { mimicking activity. (42) }\end{array}$ \\
\hline Stem & $\begin{array}{l}\text { Hydoalcoholice } \\
\text { xtraction }\end{array}$ & $\begin{array}{l}\text { High fat diet } \\
\text { fed and } \\
\text { streptozotocin- } \\
\text { Sprague } \\
\text { Dawley rats }\end{array}$ & $\begin{array}{l}100 \mathrm{mg} / \mathrm{kg} \\
200 \mathrm{mg} / \mathrm{kg}\end{array}$ & 14 days & $\begin{array}{l}\text { Anti-diabetic potential } \\
\text { through mitigating } \\
\text { oxidative stress, } \\
\text { promoting insulin } \\
\text { secretion. (43) }\end{array}$ \\
\hline Stem & Aqueous & $\begin{array}{l}\text { Alloxan } \\
\text { induced } \\
\text { diabetic rats }\end{array}$ & $500 \mathrm{mg} / \mathrm{kg}$ & 40days & $\begin{array}{l}\text { Activity of hexokinase } \\
\text { enzyme was significantly } \\
\text { increased whereas } \\
\text { glucose } 6 \text { phosphatase } \\
\text { and fructose 1,6- } \\
\text { biphosphatase } \\
\text { significantly decreased. } \\
(44)\end{array}$ \\
\hline Stem & Aqueous & $\begin{array}{l}\text { High-fructose } \\
\text { diet }(66 \% \\
\text { fructose }) \\
\text { induced }\end{array}$ & $400 \mathrm{mg} / \mathrm{kg}$ & 60 days & $\begin{array}{l}\text { Role against fructose- } \\
\text { induced insulin } \\
\text { resistance and oxidative } \\
\text { stress. (45) }\end{array}$ \\
\hline
\end{tabular}




\begin{tabular}{|c|c|c|c|c|c|}
\hline & & $\begin{array}{l}\text { diabetic Wistar } \\
\text { rats }\end{array}$ & & & \\
\hline Stem & $\begin{array}{l}\text { Aqueous, } \\
\text { alcoholic, } \\
\text { chloroform }\end{array}$ & $\begin{array}{l}\text { Normal and } \\
\text { alloxan } \\
\text { induced } \\
\text { diabetes in } \\
\text { rabbits }\end{array}$ & $\begin{array}{l}50 \mathrm{mg} / \mathrm{kg} \\
100 \mathrm{mg} / \mathrm{kg} \\
200 \mathrm{mg} / \mathrm{kg}\end{array}$ & 1 day & $\begin{array}{l}\text { Dose dependent } \\
\text { hypoglycemic Action } \\
\text { similar to glibenclamide } \\
\text { and insulin. (46) }\end{array}$ \\
\hline $\begin{array}{l}\text { Leave } \\
\text { s }\end{array}$ & Aqueous & $\begin{array}{l}\text { Maltose-fed } \\
\text { rats }\end{array}$ & $\begin{array}{l}20 \mathrm{mg} / \mathrm{kg} \\
80 \mathrm{mg} / \mathrm{kg}\end{array}$ & - & $\begin{array}{l}\text { Hypoglycemic effect. } \\
(47)\end{array}$ \\
\hline $\begin{array}{l}\text { Leave } \\
\mathrm{S}\end{array}$ & $\begin{array}{l}\text { Alcoholic, } \\
\text { aqueous }\end{array}$ & $\begin{array}{l}\text { Streptozotocin- } \\
\text { mice }\end{array}$ & $400 \mathrm{mg} / \mathrm{kg}$ & 50 days & $\begin{array}{l}\text { Hypoglycemic effect. } \\
\text { (48) }\end{array}$ \\
\hline $\begin{array}{l}\text { Leave } \\
S\end{array}$ & Aqueous & $\begin{array}{l}\text { Streptozotocin- } \\
\text { mice }\end{array}$ & $200 \mathrm{mg} / \mathrm{kg}$ & 40 days & $\begin{array}{l}\text { Hypoglycemic effect. } \\
\text { (49) }\end{array}$ \\
\hline $\begin{array}{l}\text { Whole } \\
\text { plant }\end{array}$ & Aqueous & $\begin{array}{l}\text { Alloxan-rats } \\
\text { and rabbits }\end{array}$ & $400 \mathrm{mg} / \mathrm{kg}$ & - & $\begin{array}{l}\text { Hypoglycemic effect. } \\
(50)\end{array}$ \\
\hline Stem & Aqueous & Human & $250 \mathrm{mg} / \mathrm{kg}$ & 10 days & $\begin{array}{l}\text { Cardioprotective } \\
\text { properties of vaso } \\
\text { dilatation, } \\
\text { cardiotonicactivity. (51) }\end{array}$ \\
\hline Stem & Aqueous & Human & $\begin{array}{l}150 \mathrm{mg} / \mathrm{kg} \\
300 \mathrm{mg} / \mathrm{kg}\end{array}$ & 28 days & $\begin{array}{l}\text { Decreases in blood } \\
\text { pressure and Heart rate. } \\
(52)\end{array}$ \\
\hline Stem & Alcoholic & Rats & - & 7 days & $\begin{array}{l}\text { Cardioprotective activity } \\
\text { of T. cordifolia in } \\
\text { limiting ischemia- } \\
\text { reperfusion induced } \\
\text { myocardial infarction. } \\
\text { (53) }\end{array}$ \\
\hline Stem & Alcoholic & Human & $500 \mathrm{mg}$ & 60 days & $\begin{array}{l}\text { Dyslipidemic features } \\
\text { declined by } 28.6 \%, \\
\text { metabolic } \\
\text { decreased by } 13.73 \% . \\
(54)\end{array}$ \\
\hline Root & Aqueous & $\begin{array}{l}\text { Male albino } \\
\text { rats }\end{array}$ & $\begin{array}{l}2.5 \mathrm{gm} / \mathrm{kg} \\
5 \mathrm{gm} / \mathrm{kg}\end{array}$ & 30 days & $\begin{array}{l}\text { Hypolipidemic potential. } \\
(55)\end{array}$ \\
\hline Root & Aqueous & $\begin{array}{l}\text { Male albino } \\
\text { rats }\end{array}$ & $2.5 \mathrm{gm} / \mathrm{kg}$ & 6 weeks & $\begin{array}{ll}5.0 \mathrm{~g} / \mathrm{kg} \text { body } & \text { weight } \\
\text { showed } & \text { highest } \\
\text { hypolipidaemic } & \text { effect. } \\
(56) & \end{array}$ \\
\hline Stem & Powder & Human & $50 \mathrm{mg} / \mathrm{kg}$ & 15 days & $\begin{array}{l}\text { Decrease in the level of } \\
\text { Serum Lipoprotein } \\
\text { Profile. (57) }\end{array}$ \\
\hline Stem & Aqueous & Human & $3 \mathrm{gm}$ & 14 days & $\begin{array}{l}\text { Antihypertriglyceridemic } \\
\text { activity. (58) }\end{array}$ \\
\hline Leaf & Powder & Human & $2 \mathrm{gm}$ & 60 days & $\begin{array}{l}\text { Very effective for } \\
\text { maintaining haemoglobin } \\
\text { level and total } \\
\text { erythrocyte count. (59) }\end{array}$ \\
\hline Stem & Powder & Human & $6 \mathrm{gm}$ & 60 days & It brings equilibrium of \\
\hline
\end{tabular}




\begin{tabular}{|c|c|c|c|c|}
\hline & & & & $\begin{array}{l}\text { Dosha, Dhatu, Mala in } \\
\text { the body by bringing } \\
\text { equilibrium of all the } \\
\text { vitiated Dhatus also } \\
\text { MedaDhatu to Sama } \\
\text { (equilibrium) state. (60) }\end{array}$ \\
\hline $\begin{array}{l}\text { Whole } \\
\text { plant }\end{array}$ & Aqueous & Human \& rats & 1 week & $\begin{array}{l}\text { Hypoglycaemic effect. } \\
\text { (61) }\end{array}$ \\
\hline
\end{tabular}

\section{Antidiabetic}

Experimental and clinical studies, have proven significant role of various extracts Tinospora cordifolia as antidiabetic, dyslipidemic, cardiotonic, cardioprotective as shown in Table 1. Aqueous extract of stem obtained from another species of Tinospora'Tinosporacrispa' also documented to possess the antihyperglycaemic effect is probably due to stimulation of insulin release via modulation of beta-cell $\mathrm{Ca} 2+$ concentration. This insulinotropic effect of $\mathrm{T}$. crispa is physiological proposes that the extracts contain compounds which could be used in the treatment of type II diabetes. (62) From reference 32- 50, various experimental or clinical studies, proved its role as hypoglycemic activity by insulin mimicking or some other pathway to reduce plasma glucose level. A study done in Malaysia, on another species of Tinospora cordifolia named, Tinosporacrispa extract was taken orally by Type 2 (non-insulin-dependent) diabetic patients to treat hyperglycaemia. It claimed its hypoglycaemic property by adding aqueous extract to the drinking water of normal and alloxan-diabetic rats. After one week of observation, fasting blood glucose levels were significantly lower and serum insulin levels were significantly higher in treated diabetic animals compared to untreated diabetic control. This insulinotropic action of $\mathrm{T}$. crispa was further investigated in vitro using isolated human or rat islets of Langerhans and HIT-T15 cells. In static incubations with rat islets and HIT-T15 B cells, the extract induced a dosage dependent stimulation and potentiation of basal and glucose-stimulated insulin secretion respectively. This insulinotropic effect was also evident in perifused human and rat islets and HIT-T5 B-cells, the rate of HIT-T15 glucose utilisation was not affected by incubation with $\mathrm{T}$. crispa, suggesting that the cells were viable throughout. These are the first studies to provide biochemical evidence which substantiates the traditional claims for an oral hypoglycaemic effect of Tinosporacrispa, and which also show that the hypoglycaemic effect is associated with increased insulin secretion. (61) In Ehrlich ascites tumor cells model, water, ethanol and methanol extracts of the herb, demonstrated the glucose uptake-stimulatory activity. (62)

\section{Cardioprotective}

From table 1, reference 51-53 Tinospora cordifolia claimed to have beneficial role on cardiac activity. Aqueous and Hydroalcoholic extracts of Tinospora cordifolia were administered and vital parameters, assessment of cardiac profiling were performed using cold pressor test (CPT), tilt table and platelet aggregation tests. The CPT induced arterial stiffness was counteracted by treatment with single dose and multiple doses of aqueous and hydro-alcoholic extracts Tinospora cordifolia. Treatment with single doses and multiple doses of aqueous and hydro-alcoholic extracts Tinospora cordifolia produced increase in cardiac output. (51) Tinospora cordifolia is known as an adaptogen, as it increases the resistance of the body to physical, chemical, and biological stress and builds energy, general vitality. It is observed that the aqueous extract of Tinospora cordifolia when administered on daily basis has shown improvement (increasing trend) in distance, and max speed, $\mathrm{VO}_{2}$ max and muscle power in the presence of physical stress. Tinospora cordifolia has mainly down-regulated the over activity of 
sympathetic nervous system. (52) The experimental study had done on models of myocardial ischemia-reperfusion (I /R) injury have shown dose dependent reduction in infarct size and in lipid peroxide levels of serum. The heart tissues were observed with the prior treatment of Tinospora cordifolia with various doses. (53)

\section{Hypolipidemic}

From table 1, Tinospora cordifolia have proven its hypolipidemic effect on both experimental and clinical studies. (54-58) Tinospora cordifolia indicated in the treatment of diabetes and obesity; both of which are associated with each other. It has been evaluated for their anti-diabetic and antiobese potency. Tinospora cordifolia contains multiple bioactives, which were identified to interact with multiple proteins involved in the pathogenesis of diabetes/obesity, i.e., isocolumbin with adiponectin, $\beta$-sitosterol with cholesteryl ester transfer protein, tinocordiside with lamin, berberine with JNK1 , $\beta$-sitosterol \& isocolumbin with peroxisome proliferator-activated receptor- $\gamma$, berberine with suppressor of cytokine signaling, isocolumbin with pancreatic $\alpha$ amylase, isocolumbin with $\alpha$-glucosidase, and $\beta$-sitosterol with aldose reductase.. The study suggested the probable modulation in multiple pathways in diabetes and obesity. (54) The other study indicated that Tinospora cordifolia stem extract was able to ameliorate the derangements in lipid metabolism which were associated with diabetes mellitus in streptozotocin induced diabetic rats towards normal level. It revealed the usefulness and beneficial value of this herb by enhancing HDL cholesterol levels and lowering the LDL and VLDL cholesterol levels, in treating hyperlipidemia. (55) The aqueous extract of root of Tinospora cordifolia has hypoglycemic effect, which significantly reduces the serum liver enzymes and prevents the weight gain. (56) Another study done type 2 diabetic patients, resulted significant decrease in the level of fasting blood sugar, total cholesterol, $\beta$ lipoproteins and triglycerides. The decrease in lipids and apoprotein levels of $\beta$ lipoproteins was accompanied with stimulation of plasma lecithin cholesterol acyltransferase (LCAT). It showed promising result as an hypolipidemic agent. (57) Hypertriglyceridemia is an independent risk for cardiovascular diseases. Tinospora cordifolia is composed of so many alkaloids which can lower the triglycerides without side effects. A pilot study was done on patients, which significantly depleted the levels of marker hyperglyceridemia. (58)

A clinical study was found that, leaf powder of Tinospora cordifolia was taken water have shown significant increase in haemoglobin and total erythrocyte count. It might significant role to treat the anaemia. (59) This botanical and its several developed formulations are thus were explored and established having promising potential in the management of wide range of metabolic

\section{Conclusion}

In conclusion Tinospora cordifolia could prove an excellent substitute for multidrug therapy which is currently recommended for management of various metabolic disorders. Tinospora cordifolia and its various dosage forms are reported to possess multi-targeted biological properties to manage diabetes, lipid disorders and related ailments. Rich bioactive phytoconstituents of this plant play a vital role in expression of its wide range of beneficial effects in metabolic disorders.

\section{Acknowledgements}

I would like to express my gratitude to Himalayan Journal of Health Sciences who gave me the opportunity to publish the article.

Financial Disclosure statement: The author received no specific funding for this work.

\section{Conflict of Interest}

The author declares that there is no conflict of interest regarding the publication of this article.

\section{References}

1. Sharma R, Martins N, Chaudhary A, Garg N, Sharma V, Kuca K, Nepovimova E, Tuli HS, 
Bishayee A, Chaudhary A, Prajapati PK, et al. Adjunct use of honey in diabetes mellitus: A consensus or conundrum?. Trends in Food Science \& Technology. 2020;106:254-274.

2. Sharma R, Prajapati PK. Rising risk of type 2 diabetes among inhabitants of Jamnagar, Gujarat: A cross-sectional survey. Ayu. 2015; 36:10-7.

3. Sharma V, Sharma R, Gautam DS, Kuca K, Nepovimova E, Martins N. Role of Vacha (Acoruscalamus Linn.) in neurological and metabolic disorders: Evidence from Ethnopharmacology, Phytochemistry, Pharmacology and Clinical Study. J Clin Med. 2020; 9(4):1176.

4. William C. Lloyd III, Healthgrades Editorial Staff. Matabolic Disorder.MD, FACS [Internet]. 2010 Nov 10 [cited 2021 Jan 24]. Available from: https://www.healthgrades.com/rightcare/endocrinology-and-metabolism/metabolicdisorders

5. Kumar VMD, Khanna P, Karoli R, Mahdi F. A review of antioxidant enzymes, oxidative stress, lipid profile and lipoprotein constituent in the patients of coronary artery disease (CAD) with type 2 diabetes mellitus (T2DM). Int J Bioassay. 2015; 4 (10): 4443-7.

6. Whiting DR, Guariguata L, Weil C, Shaw J. IDF Diabetes Atlas: Global estimates of the prevalence of diabetes for 2011 and 2030. Diabetes Res ClinPract. 2011; 94: 311-21.

7. Mayo Foundation for Medical Education and Research. [Internet]. 1998-2021 [cited 2021 Jan 24]. Available from:

https://www.mayoclinic.org/diseases-

conditions/metabolic-syndrome/symptomscauses/syc-20351916

8. Sharma R, Prajapati PK. Diet and lifestyle guidelines for diabetes: Evidence based ayurvedic perspective. Romanian Journal of Diabetes Nutrition and Metabolic Diseases. 2014;21(4):335-46.

9. Sharma R, Prajapati PK. Predictive, Preventive and Personalized Medicine: Leads From Ayurvedic Concept of Prakriti (Human Constitution). CurrPharmacol Rep. 2020; 6:441450.

10. Sharma R, Garg N, Verma D, Rathi P, Sharma V, Kuca K, Prajapati PK et al. Indian medicinal plants as drug leads in neurodegenerative disorders. In Nutraceuticals in Brain Health and Beyond. Academic Press. p. 31-45.

https://doi.org/10.1016/B978-0-12-8205938.00004-5.

11. Kotthahil Ayurveda [Internet]. 2021; Hospital.com [cited 2021 Jan 26]. Available from: https://www.kottathilayurveda.com/specialities/ge neral-clinic/metabolic-disorders/

12. Sharma R, Kabra A, Rao MM, Prajapati PK. Herbal and Holistic solutions for Neurodegenerative and Depressive disorders:
Leads from Ayurveda. Curr. Pharm. Des. 2018; 27(3): 2597-2608.

13. Sharma R, Kuca K, Nepovimova E, Kabra A, Rao MM, Prajapati PK. Traditional Ayurvedic and herbal remedies for Alzheimer's disease from bench to bedside. Expert Rev. Neurother. 2019; 19:359-374.

14. Sharma R, Martins N. Telomeres, DNA damage and ageing: potential leads from AyurvedicRasayana (anti-ageing) drugs. J Clin Med. 2020; 9(8):2544.

15. Acharya YT. Siddha Yoga Sangraha. Jwaradhikara. 13th ed. Nagpur: Baidyanath Ayurveda Bhavan Ltd; 2008. p. 459.

16. Acharya YT. Sushruta Samhita, Chikitsa Sthana. Reprint ed. Ch. 12, Verse 6. Varanasi: Chaukhambha Krishanadas Academy; 2004.p. 459.

17. Tripathi I, editor. Chakradatta of Chakrapani Datta. Prameha Chikitsa. Ch. 35, Ver. 25, Reprint edition. Varanasi: Chaukhambha Sanskrit Sansthana; 1997.p. 217.

18. Chunekar KC, Pandey GS. Guduchyadi Varga. Bhavaprakash Nighantu. Varanasi: Chaukhamba Bharati Academy; 2006.p. 269.

19. Shastri P, editor. Sharangadhara Samhita of Sharangadhara. Madhyam Khanda. Ch. 1, Ver. 7, 7 ed. Varanasi: Chaukhamba Orientalia Prakashan; 2008.p.126.

20. Anonymous. The Ayurvedic Pharmacopoeia of India. Part 1, Vol 1. 1st ed. New Delhi: Govt. of India, Ministry of Health and Family Welfare; 2001.p.53.

21. Tambekar DH, Khante BS, Chandak BR, Titare AS, Boralkar SS, Aghadte SN. Screening of antibacterial potentials of some medicinal plants from Melghat forest in India. Afr $\mathbf{J}$ Tradit Complement Altern Med. 2009; 6(3): 228-232.

22. Sharma R., Hetal A., Prajapati PK. Antidiabetic claims of Tinospora Cordifolia (Willd.) Miers: critical appraisal and role in therapy. Asian Pacific Journal of Tropical Biomedicine. 2015; 5(1): 6878.

23. Sharma R, Amin H. Rasayana Therapy: Ayurvedic contribution to improve quality of life. World J. Pharmacol. Res. Tech. 2015; 4:23-33.

24. Sharma R, Martins N, Kuca K, Chaudhary A, Kabra A, Rao MM, Prajapati PK et al. Chyawanprash A Traditional Indian Bioactive Health Supplement. Biomolecules. 2019;13(6): 161.

25. Sharma R, Harisha CR, Galib R, Patgiri BJ, Prajapati PK. Quantitative estimation of Satva extracted from different stem sizes of Guduchi (Tinospora Cordifolia (Willd.) Miers. J Pharm SciInnov. 2012; 1(1):38-40.

26. Sharma R, Prajapati PK. Liquid media's in BhavanaSamskara: A pharmaceutico-therapeutic prospect. J Phytopharm. 2015; 4:49-57. 
27. Sharma R, Galib R, Prajapati PK. Validation of standard manufacturing procedure of Guduchi Ghana [dried aqueous extract of Tinospora Cordifolia (Willd.) Miers] and its tablets. Ayurpharm. Int J Ayurveda Allied Sci. 2013; 2:224-32.

28. Sharma R, Amin H, Galib, Prajapati PK. Validation of standard manufacturing procedure of Guducisattva (aqueous extract of Tinospora Cordifolia (Willd) Miers) and its tablets. AncSci Life. 2013; 33:27-34.

29. Sharma R, Hazra J, Prajapati PK. Nanophytomedicines: A Novel Approach to Improve Drug Delivery and Pharmacokinetics of Herbal Medicine. Bio Bull. 2017; 3(1):132-5.

30. Prajapat R, Sharma R, Prajapati PK. Physicochemical evaluation of guduchyadikwatha for instant use: An ayurvedic herbal formulation. Journal of Pharmaceutical Research International. 2014; 2599-613.

31. Sharma R, Galib R, Prajapati PK. Antimicrobial evaluation of Svarasa Bhavita Guduchi Churna (levigated powder of Tinospora Cordifolia (Willd.) Miers with its juice). Ayurscientifica. 2017; 1(1):25-30.

32. Grover JK, Vats V, Rathi SS. Anti-hyperglycemic effect of Eugenia jambolana and Tinospora Cordifolia in experimental diabetes and their effects on key metabolic enzymes involved in carbohydrate metabolism. J Ethnopharmacol. 2000; 73(3):461-470.

33. Stanely P, Prince M, Menon VP. Hypoglycaemic and other related actions of Tinospora Cordifolia roots in alloxan-induced diabetic rats. J Ethnopharmacol. 2000; 70(1):9-15.

34. Rathi SS, Grover JK, Vikrant V, Biswas NR. Prevention of experimental diabetic cataract by Indian Ayurvedic plant extracts. Phytother Res. 2002; 16(8):774-777.

35. Sivakumar V., Dhana RM.S. Hypoglycemic and Antioxidant Activity of Tinospora Cordifolia in Experimental Diabetes. International Journal of Pharmaceutical Sciences and Research. 2011; 2(3):608-613.

36. Kinkar SB, Gopal PK. Antidibetic activity of Tinospora Cordifolia (Fam: Menispermaceae) in alloxen treated albino rat. Applied Research Journal. 2015;1(5):316-319.

37. Joladarashi D., Chilkunda ND, \&Salimath PV. Glucose uptake stimulatory activity of Tinospora Cordifolia stem extracts in Ehrlich ascites tumor cell model system. Journal of Food Science and Technology. 2014; 51(1),178-182.

38. Prince PSM, Kamalakkannan N, Menon VP. Restoration of antioxidants by ethanolic Tinospora cordifolia in alloxan-induced diabetic Wistar rats. Acta Pol Pharm. 2004;61:283-287.

39. Dhulia I, Parcha V, Pant G, Kumar D, Maithani A. Antihyperglycemic effect of methanolic extract of Tinospora cordifolia (Willd.) stem on experimentally induced diabetic rats. J Pharm Res. 2011; 4(8):2828- 2830.

40. Rajalakshmi M, Eliza J, EdelPC, Nirmala A, Daisy P. Anti-diabetic properties of Tinospora cordifolia stem extracts on streptozotocin- induced diabetic rats. African Journal of Pharmacy and Pharmacology. 2009 May; 3(5):171-180.

41. Klangjareonchai $\mathrm{T}$, Roongpisuthipong $\mathrm{C}$. The Effect of Tinospora crispa on Serum Glucose and Insulin Levels in Patients with Type 2 Diabetes Mellitus. Journal of Biomedicine and Biotechnology Volume 2012, Article ID 808762, 4 pages.

42. Patel MB, Mishra S. Hypoglycemic activity of alkaloidal fraction of Tinospora cordifolia. Phytomedicine. 2011;18:1045-1052.

43. Sangeetha MK, Balaji Raghavendran HR, Gayathri V, Vasanthi HR. Tinospora cordifolia attenuates oxidative stress and distorted carbohydrate metabolism in experimentally induced type 2 diabetes in rats. $\mathrm{J}$ Nat Med. 2011;65:544-550.

44. Sivakumar V, Mohamed SA. Hypoglycemic activity of Tinospora cordifolia in Alloxan induced diabetic rats. The Bioscan. 2009;4:75-78.

45. Reddy SS, Ramatholisamma P, Karuna R, Saralakumari D. Preventive effect of Tinosporacordifolia against high-fructose dietinduced insulin resistance and oxidative stress in male Wistar rats. Food ChemToxicol. 2009;47(9):2224-29.

46. Wadood N, Wadood A, Shah SA. Effect of Tinospora cordifolia on blood glucose and total lipid levels of normal and alloxan-diabetic rabbits. Planta Med. 1992;58(2):131-136.

47. Sengupta S, Mukherjee A, Goswami R, Basu S. Hypoglycemic activity of the antioxidant saponarin, characterized as alphaglucosidase inhibitor present in Tinospora cordifolia. J Enzyme Inhib Med Chem. 2009;24:684-690.

48. Grover JK, Rathi SS, Vats V. Amelioration of experimental diabetic neuropathy and gastropathy in rats following oral administration of plants (Eugenia jambolana, Mucurnapruriens and Tinospora cordifolia) extracts. Indian J ExpBiol. 2002;40:273-276.

49. Grover JK, Vats V, Rathi SS, Dawar R. Traditional Indian anti-diabetic plants attenuate progression of renal damage in streptozotocin induced diabetic mice. $\mathrm{J}$ Ethnopharmacol. 2001;76:233-238.

50. Raghunathan K, Sharma PV. The aqueous extract of T. cordifolia caused reduction of blood sugar in alloxan induced hyperglycemic rats and rabbits. J Res Ind Med. 1969; 3:203-209.

51. Pingali U, Kishore KK, Fatima N, Chandrasekhar N, Sravanthi IV. Evaluation of Cardiovascular and Pharmacodynamic Effects of Single and Multiple Doses of Aqueous and HydroAlcoholic Extracts of Tinospora cordifolia in Healthy Human Male 
Subjects. American Journal of Phytomedicine and Clinical Therapeutics.

52. Salve Bharat A, Tripathi RK, Petare AU, Raut AK, Rege NN. Effect of Tinospora cordifolia on physical and cardiovascular performance induced by physical stress in healthy human volunteers. Ayu. 2015 Jul-Sep;36(3):265-70.

53. Rao PR, Kumar VK, Viswanath RK, Subbaraju GV. Cardioprotective activity of alcoholic extract of Tinospora cordifolia in ischemia reperfusion induced myocardial infarction in rats. Biol Pharm Bull. 2005;28:2319-2322.

54. Mandar, B.K., Khanal, P., Patil, B.M. et al. In silico analysis of phytoconstituents from Tinospora cordifolia with targets related to diabetes and obesity. In Silico Pharmacol. 2021;9:3 https://doi.org/10.1007/s40203-020-00063-w

55. Nagaraja PK, Kammar KF, Sheela DR. Efficacy of Tinospora cordifolia (Willd.) extracts on blood lipid profile in streptozotocin diabetic rats. Is it beneficial to the heart? Biomed Res. 2008;19:9296.

56. Sparshadeep EM, NayakRP, Kavana GV, RaiM. Evaluation of hypolipidemic effect of Tinospora cordifolia in cholesterol diet induced hyperlipidemia in rats. International Journal of Basic \& Clinical Pharmacology. 2016 Aug; 5(4):1286-92.

57. Kumar V, Mahdi F, Singh R, Mahdi AA, Singh RK. A clinical trial to assess the antidiabetic, antidyslipidemic and antioxidant activities of Tinospora cordifolia in management of type - 2 diabetes mellitus. International Journal of Pharmaceutical Sciences and Research. 2016;7(2):757-64.

58. Shirolkar A, Yadav A, Mandal TK, Dabur R. Intervention of Ayurvedic drug Tinospora cordifolia attenuates the metabolic alterations in hypertriglyceridemia: a pilot clinical trial. Journal of Diabetes and metabolic disorders; 2020.

59. Tripathi N, Choudhary A. Magical effects of Tinospora cordifolia leaf powder supplementation on erythrocyte count and haemoglobin levels of anemic obese women. World Journal of Pharmaceutical Research. 3(2):2585-89.

60. Sharma M, Murthy AR, Rath SK, Sharma U. Clinical study on Guduchi (Tinospora cordifolia willd.) And Mustak (Cyperus Rotunduslinn.) in sthoulyawith special reference to overweight. Journal of Pharmaceutical and Scientific Innovation. 2019; 8(6).

61. Noor H, Hammonds P, Sutton R, Ashcroft SJ. The hypoglycaemic and insulinotropic activity of Tinosporacrispa: studies with human and rat islets and HIT-T15 B cells. J Ethnopharmacol.1998 Aug;62(1):7-13.

62. Noor H, Ashcroft SJ. Pharmacological characterisation of the antihyperglycaemic properties of Tinospora crispa extract. J Ethnopharmacol. 1998;62(1):7-13.

63. Sharma R, Kumar V, Ashok BK, Galib R, Prajapati PK, Ravishankar B. Evaluation of hypoglycaemic and anti-hyperglycaemic activities of Guduchi Ghana in Swiss albino mice. Int $\mathrm{J}$ Green Pharm. 2013;7:145-8.

64. Sharma R, Kumar V, Ashok BK, Galib R, Prajapati PK, Ravishankar B. Hypoglycemic and anti-hyperglycemic activity of Guduchi Satva in experimental animals. AYU. 2014;4:217-20.

65. Sharma R, Shukla VJ, Ravishankar B, Prajapati PK. The effect of two different dosage forms of Guduchi i.e. Satva and Ghana WSR antihyperglycemic effect on madhumeha (NIDDM) [dissertation], Gujarat Ayurved University, IPGT and RA, Jamnagar; 2012:132-3. 